\title{
THE RECLAMATION, DISTRIBUTION OF, AND SETTLE- MENT IN NEW CULTIVABLE LAND, WHETHER OR NOT COMBINED WITH LAND CONSOLIDATION, WITH A VIEW TO IMPROVING THE AGRICULTURAL STRUCTURE OF THE NETHERLANDS ${ }^{1}$ )
}

\author{
S. HERWEIJER
}

The following article is based on a lecture given by Mr. S. Herweijer, Director of the Government Service for Land and Water Use in The Netherlands, at the Agricultural Conference of the Landeswirtschaftskammer für Nieder-Österreich und Wien held in Vienna on March 13, 1956.

The lecture deals with some aspects of the structural improvement of areas where farms are poorly equipped and undersized.

It was published in German in Der Förderungsdienst Vol. 4, Number 12 (December 1956) p. $367-374$.

Although much of this lecture is inapplicable to English-speaking countries, the editorial committee of the Netherlands Agricultural Journal is of the opinion that the remarks made are of such importance for projects which may be carried out in other countries that it is here also reproduced in English.

The Edtorial Committee.

\section{INTRODUCTION}

This article deals with some agricultural problems which are very important for the development of agriculture in the Netherlands.

It may be useful to outline first of all the economic development of the Netherlands and the place occupied by agriculture within this framework. Reference will then be made to what is being done by the Government in co-operation with the agricultural organizations to ensure that Dutch agriculture makes the highest possible contribution towards the national economy.

\section{SOME FEATURes OF DUTCH ECONOMY}

The most characteristic feature of the demographic development of the Netherlands and the related economic development is without doubt the rapid rise in the country's population.

Whereas there were nearly 8 million inhabitants in 1930 , the population has now grown to more than 11 million.

The population of the Netherlands increases by $10 \%$ every ten years, which means that 100.000 children are born every year. It is clear that this is of paramount significance to a small country such as the Netherlands, which is slowly but surely developing from an agricultural state into an industrial one. In the thirties about 18 to $22 \%$ of the Dutch population were employed in agriculture, but this percentage has been steadily decreasing proportionally and there is even an absolutely decrease. To-day only from 12 to $14 \%$ of the population is engaged in agriculture, which means that despite agricultural improvements and land consolidation, reclamation and impoldering works, agri-

1) Received for publication April 11, 1957. 
culture is unable to provide employment for all the children of agricultural families.

In itself this is not an unhealthy phenomenon, but it creates special difficulties for the entire Dutch economy and will therefore be considered here in greater detail.

\section{SPATIAL DEVELOPMENT OF AGRICULTURE}

When we view the development of agriculture in the Netherlands since the last century the following broad outline is presented.

In previous centuries large areas were brought under cultivation. Thus the western part of the Netherlands, most of which is below sea-level, was reclaimed and cultivated as a result of the construction of dykes and the use of drainage windmills which were later replaced by steam pumps. It is in this district that we find the extensive agricultural areas with comparatively recent allocation in which there are usually good farms. The oldest agricultural areas, which are still under cultivation, are in the eastern part of the Netherlands; during the last century they were considerably enlarged by the reclamation of large tracts of moorland and peat-moor. In the last century and the first half of the present one in particular the reclamation of wasteland was able to assume large proportions after the introduction of the steamplough and the use of fertilizers. Many new farms were established in these areas.

Moreover in the thirties the reclamation of moor and peat-moor land proceeded vigorously, these projects taking advantage of the widespread unemployment with which the Netherlands were also afflicted at the time.

In the thirties the Government built large labour camps in these reclamation areas for the weekly accomodation of workmen who came from places with unemployment and helped to reclaim large areas of wasteland. During this period the Government greatly encouraged the execution of land improvement works by granting subsidies for this purpose. In the first instance this provided work for the unemployed and secondly it stimulated the national economy because these unemployed workers, who received a good weekly wage as a result of this relief work, were able to increase their purchasing power to its former level.

Consequently modern land improvement in the Netherlands is largely based on the great activities of the thirties. But this is only one aspect of the matter. The other possibilities existing in the Netherlands have also been turned to account, especially after 1920. The Government of that time decided to enclose the Zuiderzee, as it was then called, thus separating it from the North Sea, and to create on the bottom of the enclosed sea 5 large agricultural areas ranging from 20.000 to nearly 50.000 hectares.

This scheme was also carried out, and between 1920 and 1930 a large enclosing dam was built which separated the Zuiderzee from the North Sea. 1930 saw the completion of the dykes of the first polder, named the Wieringermeer, which covered an area of 20.000 hectares. In the years that followed the new polder was brought under cultivation and made inhabitable, and in the meantime work was started on a new polder called the North-East-Polder. This polder was drained in 1940 and was brought under cultivation and made inhabitable in the ensuring period, although the work was, of course, delayed 
by the war. This polder covers 48.000 hectares and is therefore able to make a considerable contribution towards the development of agriculture.

To-day we are in the first stage of the third polder, viz. the East Flevoland Polder. The dykes have been completed, the large pumping stations are nearly ready for use and in 1956 the services concerned began pumping out a body of water nearly $6 \mathrm{~m}$ thick.

This polder will have been drained by the end of 1957 and can afterwards also be made cultivable and inhabitable.

It is obvious that large scale works are required in such extensive areas of virgin land. A great amount of planological work has to be done such as building towns and villages, constructing roads, harbours, canals and bridges, laying on water and electricity, and the like, and finally, making provision for settlement, including the construction of farm buildings, before such a virgin sea-bottom, lying, moreover, 5 to 6 metres below sea-level, can be converted into a prosperous agricultural area. These reclamation works are chiefly mentioned in order to show their connection with the improvement of the agricultural structure of the older areas.

It should not, however, be concluded from the above that our area of cultivated land is being constantly extended.

As a result of work carried out in the sphere of town and country planning we lose about 3000 hectares of cultivable land every year. The extension of towns and villages, the construction of roads for the rapidly increasing traffic, the construction of harbours and industrial sites, recreation grounds and the like, require large areas of cultivated land, especially in the western part of the Netherlands. As mentioned above it is, in fact, the rapid growth of our population that leads to a great expansion of our industry, particularly in the west of the country where the Rhine empties itself into the North Sea.

It is a world-wide phenomenon that where a large continental river meets the sea large conurbations always develop. The growth of the Dutch conurbation, called Holland border town, was particularly marked in past-war years.

The big towns of Amsterdam, The Hague and Rotterdam are extending very rapidly and this is the very area in which the best cultivable land is situated.

The area required for the said town and country planning may be estimated at 2500 to 3000 hectares. On comparing the figures it can be seen that the extension of the area of cultivated land resulting from the Zuiderzee reclamation and other estuaries, plus the extension resulting from the execution of land improvement works such as reclamation, are together slightly more than the total losses resulting from the above-mentioned town-housing and planological schemes.

RESULTS OF THE INCREASE IN POPULATION AND THE REDUCTION OF AGRICULTURAL ACREAGE

Hence the Netherlands the area of cultivated land recovered more or less offsets the area lost. Our task is therefore to practise agriculture as efficiently as possible on the existing area. In the twentieth century this means, however, that owing to intensive rationalization and mechanization the number of agricultural workers that can find employment in a given area is unable to increase, and rather tends to decrease. From this it follows that the increase 


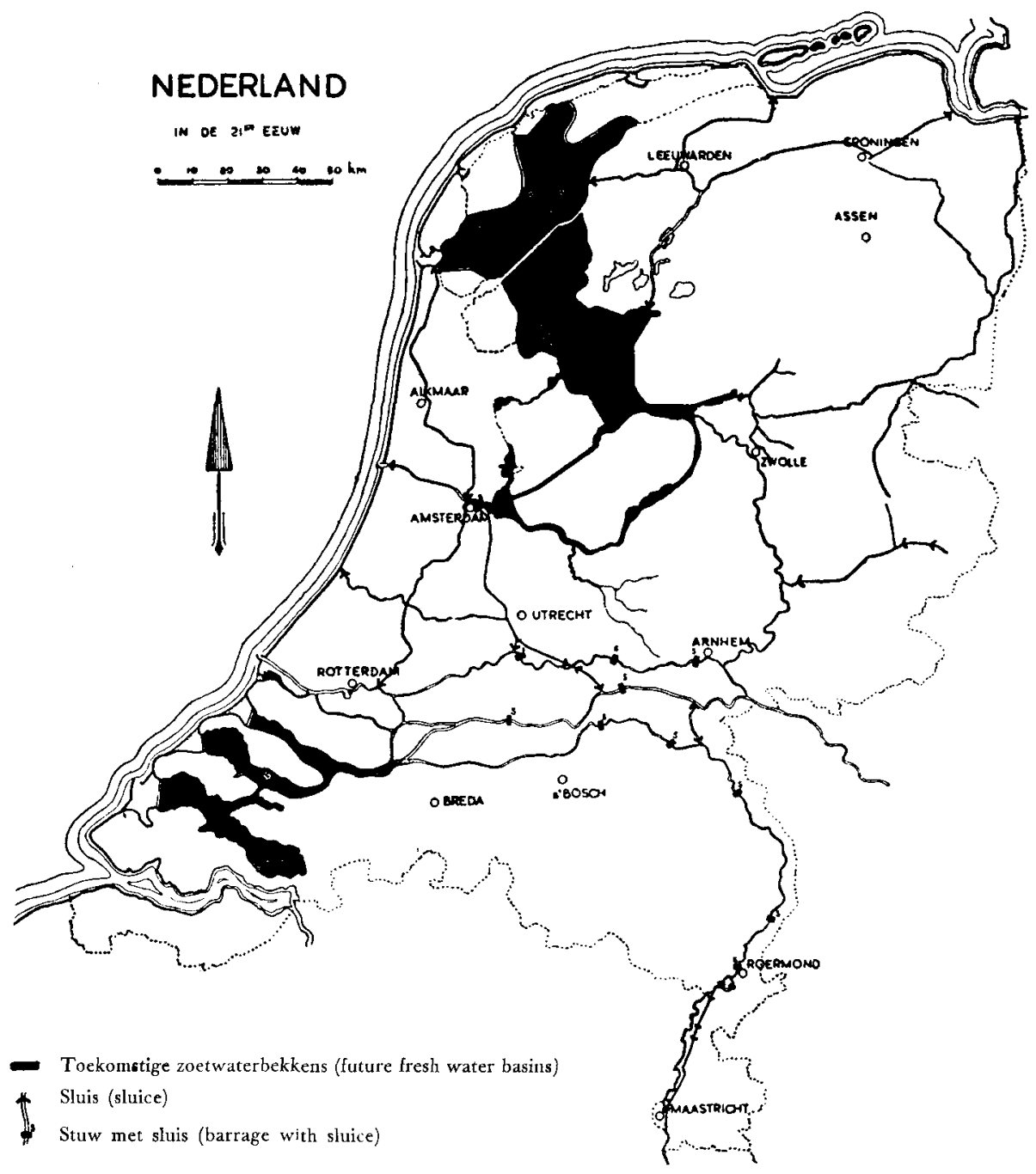

Fig. 1 The Netherlands in the 21st century. What the map of the Netherlands will LOOK LIKE WHEN THE FUTURE HYDRAULIC ENGINEERING WORKS HAVE BEEN COMPLETED. (Published in J. Th. Thysse, "De zoetwatervoorraden in Nederland". Landbouwkundig Tijdschrift 63 (1951), p. 680).

in our vocational population must be entirely absorbed by industry. In view of the said great increase in population it will also be clear that in the Netherlands one of the first requirements is to develop industry. Moreover if agriculture is to develop it is essential that those who are born in an agricultural environment should mainly find employment in industry.

Industrialization has been greatly encouraged by the Netherlands Government since the last world war. This industrial development is particularly evident in the steel and metal and chemical industries. It will be clear that these large industrial investments also require large imports and it is therefore extremely important that Dutch agriculture should contribute towards a favourable balance of trade. 
Agricultural production in the Netherlands has always been largely orientated towards foreign markets. Of the total production nearly $2 / 5$ is exported. On the other hand Holland imports large amounts of foreign-grown breadgrains (wheat) and some coarse grains.

The imported coarse grains and other imported feeding stuffs are mainly exported in the form of pork and eggs. At the present levels of consumption the Netherlands is self-sufficient as regards the production of vegetables, fruit, eggs, milk, milk products, meat, potatoes and sugar. There is, however, a shortage of bread grains and vegetable fats. Exports of the products of arable farming, horticulture and cattle farming mainly consist of re-exported homeproduced raw materials. On the other hand the export products of pig-breeding and poultry farming are chiefly re-exported feeding stuffs, the remainder being mainly labour.

For the whole Netherlands economy a vital agricultural industry producing at low cost prices is of the greatest importance. This is more than ever the case to-day now that the Netherlands has to introduce large-scale industrialization as a result of the great increase in population. This progressive industrialization benefits by relatively low wages with a high actual purchasing power. This is to the interest of employer, worker and industrial investor, as will be clear when we consider that a skilled manual worker in Holland spends $35 \%$ of his wages on food, of which one half is represented by raw materials supplied by the farmer and the other half is intended for processing by industry and distribution by the retail trade. The close interrelation between agriculture, industry and trade is clearly shown by the following figures.

Of the total Dutch agricultural production, representing a value of Dfl. 4300 millions, Dfl. 1700 millions worth is supplied to the Dutch processing industry, the percentage for milk being as high as $83 \%$ and for sugar-beet $100 \%$.

Moreover the following figures give a good idea of the position of Dutch agriculture. Of the total of Dutch exports, $38 \%$ consists of agricultural products, viz. $13 \%$ of unprocessed products of Dutch origin and $25 \%$ of agricultural products processed by the Dutch food processing industry.

Thus it can be seen that in the first place Dutch agriculture feeds a large part of the rapidly increasing population, and in the second place makes a very considerable contribution towards exports. Hence its national characteristic is intensive production coupled with a high degree of rationalization. The Government's agricultural policy consequently aims at constantly improving the productive technique of agriculture; at the same time it has a valuable instrument in its market and price policy by which production in the Netherlands can be directed towards such products as are required for consumption and also afford the greatest possibilities for export.

In this paper it is not intended to deal with the instrument of price-policy as we know it in the Netherlands within the framework of the agricultural policy. We shall only describe such measures as aim at improving the internal and external structure of farms.

INTERNAL AGRICULTURAL PRODUCTION FACTORS

After 1890 the Netherlands Government used its powers to an increasing extent for the purpose of improving agricultural production.

In the last few decades of the last century it was found that Dutch agri- 
culture was lagging behind that of Denmark, for example. Since 1890, therefore, it has been the constant aim of the Government to improve the technique of farmer and market gardener by agricultural education and building up an agricultural advisory machinery, the basis of the development of the farmer being education and agricultural education in particular.

The advice given by the Government Agricultural Advisory Service may help the farmer to extend the knowledge he has gained so that he is able to combine soil, labour and capital on his farm in the most economic way.

In farming the so-called internal productive conditions are very important. By this is meant in the Netherlands such productive conditions as can be altered by the farmer or the market gardener from the outset and adapted to modern standards. In principle the farmer can himself improve his production plan, manuring, water management, soil improvement, equipment and financing. Whether he improves these internal productive conditions will depend on several factors. In the first place the economic climate should be such as to justify his expectation that the steps he has taken to improve his farm will actually give a return. It is for this reason that especially after the last war the basic aim of the policy of the Dutch Government has been to ensure a reasonable remuneration from well-managed and socially and economically sound farms.

Secondly, the farmer should have the knowledge and skill to improve his internal productive conditions and finally, he must have the required financial resources. It may, in fact, be said that all these requirements are reasonably met by the many Government measures that have been taken in the last ten years. Thus it is particularly agricultural education and advisory work and, as regards financing, the co-operative agricultural credit banks, backed by the so-called agricultural security fund set up in 1950 to provide security for farm credits granted by agricultural credit banks, that make it possible for the farmer to improve internal productive conditions on his farm.

\section{External agricultural production factors}

In the case of the external productive conditions the position is quite different. By external productive conditions we mean productive conditions in which the farmer or market gardener can make little or no improvement by himself, but which can only be improved on a communal basis. Some examples of this are farm size, water control, parcelling out and development, the quality of the soil, the tenancy relations, and the provision of such facilities as piped water, electricity and telephone.

Now experience in the Netherlands shows that these so-called external productive conditions are very unsatisfactory in many areas. This is especially true of the very old agricultural areas which have long been under cultivation. Many agricultural areas are so handicapped by poor external productive conditions that it would be exceedingly difficult to run the farms on an economic basis even if their internal productive conditions could be improved. Each external productive factor has its own effect and the social, farming economy and structure survey carried out in the Netherlands after the last war, and for which we have a separate Agricultural Economics Research Institute, have shown in particular that these external productive conditions exert a varying, but very marked effect on the farm's profitability. 
such farms are continually reduced in size, while in other parts of the country there is no such custom and the entire farm passes to one son.

Housing and the environment of the farm population also have an effect on the economic aspirations of the population. It is true to say that poor housing conditions are usually accompanied by economic backwardness.

Hence it is the sum of all these conditions that determines the structure and prosperity of the countryside. The various groups of conditions influence each other, but there is also an interplay within each group. In the economic and land-improvement survey now being carried out by the AgriculturalEconomics Research Institute and the Government Service for Land and Water Use, our aim is to determine as accurately as possible, both qualitatively and quantitatively, the social and mental conditions applicable to each area and to give an accurate definition of their effect on the development of prosperity. Using the results of these surveys as the basis, it is eventually decided what measures should be taken in the areas concerned in order to improve the agricultural structure.

\section{FARM STZE}

In connection with the subject of this article we will now discuss rather more fully the question of farm size.

The situation in the Netherlands is that of all Dutch land users occupying more than 1 hectare, $42 \%$ run a farm of less than 5 hectares, $27 \%$ a $5-10$ hectare farm, $20 \%$ a 10-20 hectare farm, $10 \%$ a $20-25$ hectare farm and only $1 \%$ a farm of more than 50 hectares. In terms of area this means that out of the entire area of cultivated land in the Netherlands $31 \%$ is managed by farmers whose farms are smaller than 10 hectares.

The cost-price survey being made in the Netherlands of the various products of a large number of individual farms shows that it is especially on very small farms that the cost-prices of products are high.

It is clear that apart from the quality of the farmers concerned, this situation can only be changed either by enlarging the farms or increasing labour productivity on the small-holdings, to a considerable extent. The latter is only possible when there is very intensive production on the very small farms and this can only be achieved if smallholders purchase large quantities of concentrates for pig-breeding and poultry farming. It is obvious, however, that this production is very sensitive to the state of the market so that for safety's sake an attempt is being made in the Netherlands to increase the size of the very small farms through direct and indirect measures.

It is these areas in particular with many smallholdings that suffer from hidden agrarian unemployment. Consequently in recent years we have been paying much attention to the sociographical and demographical survey of areas containing many smallholdings. Fortunately we see that a great number of smallholdings are disapearing because the smallholders' sons are attracted by industry in which they can earn higher wages than on the parental farm. On the other hand, unfortunately, we also see a constant splitting-up of larger farms, so that this progressive mechanization and fragmentation of larger farms again causes hidden unemployment. In order to quantify this survey in a better way we have introduced what is called the vocational choise index. This means that when on a given farm there is one successor, the vocational 
choise index is put at one; when, however, there are more successors the vocational choise index is higher than one and on the other hand when there are fewer successors, the vocational choise index is less than one. Surveys made in the Netherlands in 1948 and 1952 show that the 1-5 hectare farms generally have a vocational choise index of 0.9 , which means that in this case a complete successor has still to be found, which is a favourable tendency. But on the other hand we see the opposite in farms of more than 5 hectares. In the group with 5 to 10 hectares the vocational choise index is 1.3 , in the 15-20 hectare farms 2, the 20-30 hectare farms 2.6 and farms of 30 hectares and upwards 3.0. This means that as a rule the average vocational choise index in the Netherlands is still 1.4 and is far too high on large farms in particular. This shows that in the Netherlands there is still a constant tendency for farms to be split up. Hence on larger farms there are still too many farmers'sons who want to be farmers. This leads on the one hand to an undesirable splitting-up and on the other to hidden unemployment, and finally, what is also very important, to what is called vocational degradation. When, for instance, there are three sons on a farm, when they have reached the age of 30 or 40 they may come to the conclusion that they are unable to own their own farm, and they therefore change over to industry as unskilled workers. This is why increasing attention is being given to vocational guidance for agrarian families.

We hope that in the future farmers and farmers'wives will make an increasing use of vocational guidance bureaus of which there are still too few in the country. For this reason it is also important to establish trade schools in areas with a high agricultural vocational choise index.

Direct CONCREte measures in the Netherlands to eXtend the SMallholdings

Our purpose is not only achieved by giving such vocational guidance and preventing farms from being split when estates are partitioned, but also by carrying out land improvement works accompanied by increases in the size of farms.

In this sphere much experience has been gained in the Netherlands since 1945. As was mentioned at the beginning of this article the 20.000 hectare Wieringermeer polder was reclaimed from the Zuiderzee during the thirties.

This polder, then, was reclaimed by the State, and from the very first the Government decided not to sell the land to its future occupiers. Instead it is leased out. This, too, is a very proper procedure under conditions in the Netherlands where there has been a very efficient Land Holding Act since 1937. This act provides that when a person holds land on lease from the State both he and his direct successor is entitled to continue the lease. Under these conditions farms have been rented in the Wieringermeer polder by 476 farmers. In general it may be said that the majority of farmers came from all different partts of the country, and by this settlement they have not made any direct contribution towards improving conditions on the old land where there were too many smallholdings.

After the last war there came a change. Several areas had been badly hit by the war, one of the worst effected being the 18.000 hectare island of Walcheren which projects into the North Sea in the south-west of the Netherlands. This island was inundated by salt water as a result of allied bombard- 
ment during the liberation of Europe. For a year the island was in open tidal connection with the sea and so much damage was caused that entire reconstruction was necessary.

The Government and the States-General passed a special act for the rehabilitation of the island, providing for a completely new system of roads and watercourses. It was also possible to re-establish the damaged farms and steps were taken to increase the size of the many small farms on the island. These farms were enlarged in the following way.

The reform was carried out from 1945 to 1952. First of all a new plan of roads and watercourses was carried out within the framework of a general scheme of land consolidation.

Moreover many small lots were re-grouped and combined so that their size was considerably increased and finally, the soil condition of these various lots was also improved.

Simultaneous with this reform, for three years farmers were given the opportunity to apply for a transfer to the North-East Polder. In three years applications were received from some 200 farmers, 118 of whom were selected for transfer to the new State polder in the Zuiderzee. As at this period there was not much experience in this sphere, the farmers were allowed to leave as they were and they now lease farms in the new Zuiderzee polder. Many, however, did not sell their land on Walcheren but remain in possession of it. This has subsequently proved to be a disadvantage. Owing, however, to the departure of 118 farmers, who together left behind 1947 hectares, it was possible to increase the average farm-size on the island from 6.16 to 10.3 hectares, which means that farms could be practically doubled in size.

In 1953 the Netherlands was overcome by a disaster. As a result of a violent storm more than 100.000 hectares of cultivated land were flooded by sea-water. After the dykes had been repaired it was found that about 35.000 hectares had been devastated; most farm buildings had been demolished, and roads and watercourses were seriously damaged, so that complete reconstruction was called for. The Government therefore decided to apply the abovementioned (Walcheren) Reform Act to these areas as well. This Act is now being implemented and in this area also full advantage is being taken of the possibilities of farm extension which the act provides for.

96 farmers have already left these areas for the North-East Polder where they have obtained a new farm. They left behind 2749 hectares for land consolidation. 1600 hectares of this is freehold and 1000 hectares leasehold land. Farmers moving to one of the modern State polders are now required to sell their freehold land to the Reform Committee which, under the land consolidation scheme, resells it in turn to farmers with small farms wich can thus be enlarged. The reason why this step is taken is that otherwise a son of a migrant farmer could return whenever he wished in order to occupy the land left by his father.

On the whole this method is very satisfactory and the Reform Act which now applies to 50.000 hectares is working very well. The Government is consequently devoting much attention to the problem of enlarging farm area and carrying out land consolidation at the same time. Two years ago it set up a State Committee whose task was to investigate whether in future it would be desirable to use all newly-recovered land in the Zuiderzee for the 166 


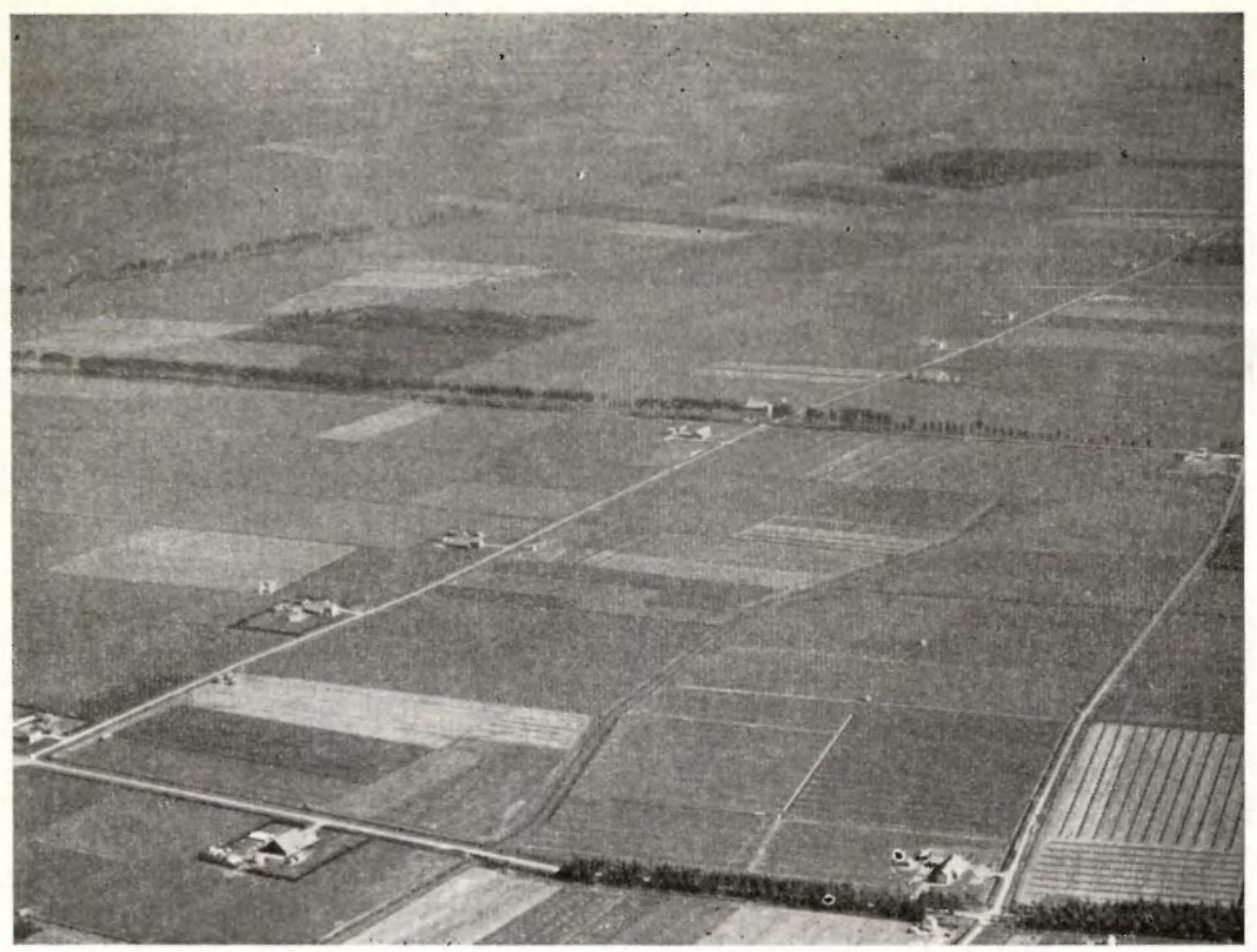

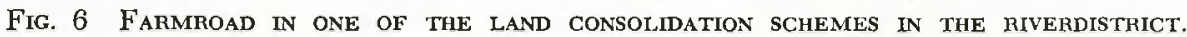

Photodraph Royal Dutch Airlines-Aerucurtio.

purpose of enlarging undersized farms on the old land. The State Committee is still studying this matter and has not yet arrived at a definite conclusion. It may be expected, however, that the Government's policy will be more and more in this direction, as it has been decided that, by way of experiment, five other areas in the north and east of the Netherlands will be reformed. This reform will also include land consolidation and co-operation with the North-East Polder. These trial areas cover more than 9000 hectares, and in this case also, at the same time as a land consolidation project is undertaken a number of farmers will be given the opportunity to move to the North-East Polder. It is now the fixed rule in these areas that farmers who quit must sell their freehold land to the reform committee. This measure was taken for the same reason as was mentioned above with reference to the reform in the south-west of the country.

The general conclusion is that these reforms can only be carried out satisfactorily if combined with land consolidation, since the whole agricultural and planological structure of an area is, in fact, changed. Under the Dutch system, financing is carried out as follows.

\section{Financing FarmeXtensions}

When land consolidation has begun the land contributed by each freeholder is valued. At the end of the procedure each freeholder's new property is valued and the difference between these amounts may be paid off by the owner over thirty years at a low rate of interest, viz. $3 \%$. As a rule it may 


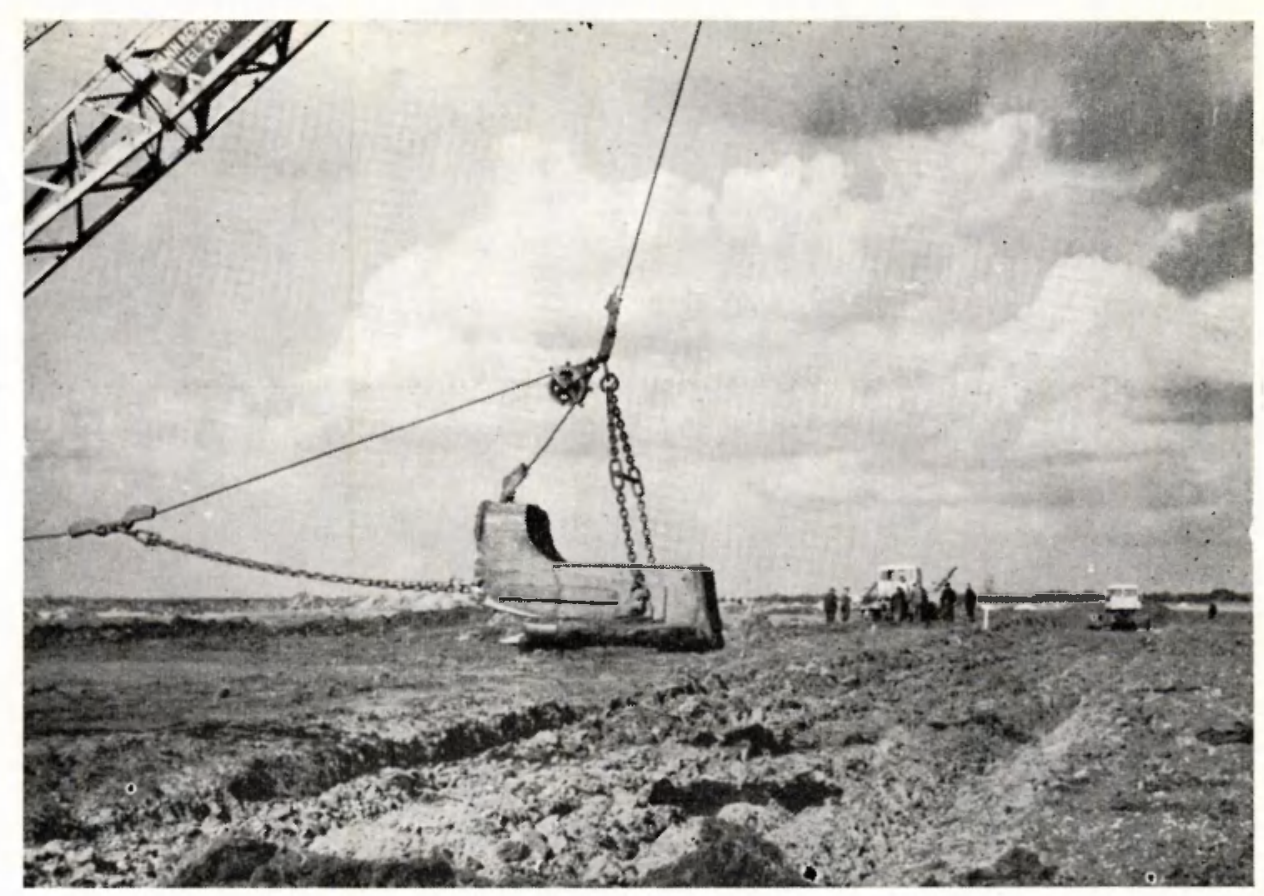

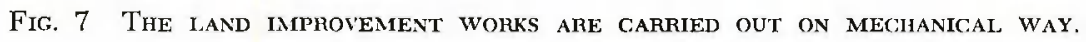

be assumed that the Government grants a subsidy of from 70 to $80 \%$ for carrying out all works, including the building of farmhouses, the construction of roads and watercourses, the improvement and joining of land and the laying of piped water and electricity.

It will be clear that smallholders whose holdings are thus enlarged are faced with considerable difficulties, these being of two kinds.

In the first place, a farmer who has hitherto been managing a very small farm is suddenly compelled to change over to a larger farm. For this reason smallholders on reformed farms must be enabled to extend their knowledge of the management of large farms by supplying them with special courses and guidance lectures.

In the second place, a small farmer whose farm has been considerably enlarged should be in a position to replace or extend his equipment and adapt his herd to new conditions. For renewal, improvement and extension of his farm equipment and livestock the Government has set up an agricultural security fund. This security fund undertakes $50 \%$ of the security to be given by farmers when they borrow money from an agricultural credit bank. This means that farmers can also obtain a credit from the agricultural credit bank without being able to give sufficient security themselves. This provision is very essential when farms are enlarged as otherwise farmers with enlarged farms may not have the financial resources for operating them on modern lines. From 1945 to 1950, when the agricultural security fund was still non-existent, it was often noticed that farmers sub-let to bigger farmers the land they had received for enlarging their farm. For this reason, in areas where farms are 
being enlarged much attention is paid to improving the smallholder's equipment, mentally, spiritually, technically and financially.

\section{The SPIRITUAL AND MENTAL DEVELOPMENT CONSEQUENT ON FARM ENLARGEMENT}

This spiritual and mental equipment is, indeed, very important. It is just as difficult for a small grocer to suddenly become branch manager of a fairly large department stores as for a very small farmer to suddenly adapt himself to a much larger farm. It is for this reason that in reformed areas the necessary knowledge is imparted to farmers by the Agricultural Advisory Service. The farmers' organizations, in turn, and the women's rural institutes, have the important task of preparing farmers both spiritually and mentally for farm extension and constantly advising them while the extension activities are in progress. A necessary complement is that farmers whose farms have been enlarged, as well as the others who have more than one son, should give a non-agricultural training to the sons who will not succeed them so as to prevent the farm from being split up at a later date. Consequently these reformed areas are the very ones in which it is necessary to give vocational guidance. If this is not done the results attained will again be cancelled out. Thus a good reform system has many advantages. But it should not be imagined that this is a simple matter. It takes at least 3 or 4 years to prepare areas intensively for these measures. A number of farmers, usually quite a considerable number must be prepared to migrate to an entirely different part of the country. In Holland migrating farmers have to continue farming at a distance of $100 \mathrm{~km}$ from their original birthplace and domicile, and this is no easy task, particularly for the rather conservative-minded farmers' families. It is obvious, therefore, that a sufficient preliminary period is required to prepare the farmers and their wives for this migration. This preparatory process should be especially supported by the farmers' organizations which, of course, have more influence with farmers in this respect than the Government has. Secondly, care should be taken that the families who leave are not only the most active ones. If the potentialites of the new area are particularly great there will obviously be a tendency for the good farmers to leave. If the committee entrusted with carrying out the reform does not ensure that active farmers also stay behind in the area concerned there is bound to be anaemic tendency in the reformed area, particularly if the larger farmers leave.

Consequently our attitude is that in the event of land reform both large, medium and small farmers should leave for the new area. This has two consequences. Firstly, provision should be made in the new area for both large farms and small ones. Consequently 12, 18, 24, 30,36 and 48 hectare farms have been created in the new Zuiderzee polders. Secondly, care should be taken to ensure that migrating farmers do not obtain more land, or at any rate very much more land than they had in the old area. This means that a farmer occupying a 7 or 8 hectare farm in the old area may have his land increased to 12 hectares but not to 18 . In the same way, a farmer occupying 22 hectares in the old area may receive 24 hectares, but not 30 or 36 . The general rule in the Netherlands is that a migrating farmer receives a farm equal to or larger than the economically justified minimum size and one, moreover, which differs as little as possible from the farm size he had in the old area. This measure was taken in the first place to prevent the need of too 
much land in carrying out the reform, and secondly to prevent too great jealousy among farmers.

At first sight all these points may seem minor ones but they are extremely important for good reform. As was already mentioned, there is a State Committee in the Netherlands which examines whether this method should continue to be followed in the future.

As was stated, in the first Zuiderzee polder only 3 or $4 \%$ of the land was used for reforming the old areas. In the second polder this figure is as high as $20 \%$ and there is every reason to believe that this percentage will rise to 40 or $45 \%$ rather than fall.

It will be clear that if on the one hand, we thus continue to bring new areas into cultivation in the Zuiderzee, we have, on the other hand, the possibility of reforming and consolidating old areas and also raising the level of farming economy.

\section{THE OPTIMUM FARM SIZE}

One of the most important problems in reforming an old agricultural area is the minimum farm-size for the purpose envisaged.

It may even be asked whether there should be a minimum farm size for the various agricultural areas. Or should the farmer's person be taken into account?

Secondly, does reform apply to farms or farmers? For instance, the view may be held that a 3 hectare farm occupied by, let us say, a farmer of 62 who has no successor, cannot be reformed as it is likely to be discontinued within a few years. But we can argue from another point of view and say that this farm needs reforming as otherwise there is a good likelihood that when the farmer, who is now 62 , dies or stops farming, there will be another to carry on the farm. It may also be asked whether a farmer aged 45 , for example, who has a submarginal 3 hectare farm should be reformed irrespective of his mental and spiritual outlook and his agricultural knowledge.

Thus there are still many problems to solve in the sphere of farm extension and the various reform committees are far from being in agreement on the matter.

The following view is usually held. Firstly, only those persons are eligible for reform whose chief occupation is agriculture, or horticulture, i.e. they derive more than $50 \%$ of their income from these vocations. Secondly, a farmer will only be reformed if he has a good reputation and is considered capable of managing a larger farm.

This admittedly involves a subjective judgment, but there does not seem to be any other way of tackling the problem. In such a case it is impossible to work according to a set, dogmatic formula.

Another question is the degree of enlargement. On this matter opinions still differ in the Netherlands. One group believes that, depending on the type of farm in the region, farms should be enlarged to a size enabling a single worker, viz. the manager, to utilize his entire capacity for work in a rational way. According to this line of thought, the minimum farm size in the Netherlands should range between 7 and 10 hectares. On the other hand there is another group which is of the opinion that the first consideration should be that the farmmanager should have a successor for a considerable time. 
Actually, therefore, there should be work for two sons. Moreover, this group believes that mechanization will increase to such a degree that in carrying out the present reforms the minimum farm size should not be too low, and should actually be about 14 or 15 hectares. We are inclined to follow a middle course, viz. that the minimum farm should provide work for not less than one person and that as regards the future one should allow for a high degree of mechanization. It is anticipated that in the coming decades agricultural mechanization will have to increase considerably to enable agriculture to compete with industry, and for this reason the minimum farm size should not be too low. Otherwise the farms now enlarged will again be faced with too low labour productivity in a few years'time.

\section{ENLARGING FARMS BY BUYING OUT FARMERS ON A VOLUNTARY BASIS}

The above methods of enlarging farms are not the only ones applied in the Netherlands. Under the new Land Consolidation Act of 1954, the committee entrusted with the land consolidation of a specified area may buy out on a voluntary basis persons intending or prepared to retire from agriculture. In this case not only is the land purchased, but these persons may also receive a kind of compensation for loss of profits because they wish to stop farming. Such a policy is conceivable in the case of a farmer, aged 64 , for example, who occupies a 30 hectare farm. While land consolidation is being carried out he is approached by the local land consolidation committee. In pursuance of the Act the committee may offer to purchase from him the 30 hectares plus the farm buildings at the current price and give him an additional amount of, say, Dfl. 1000,-- per hectare, or Dfl. 30.000,- extra, in consideration of the fact that he is liquidating his farm. The land which thus becomes available may be used by the local land consolidation committee for enlarging small farms.

The Act also provides that in such a case the compensation for loss of profits, viz. the buying-out compensation, is to be borne by the State. This is important because it means that this expense is not charged to the project, unlike the cost of land improvement works, which, in principle, are entirely charged to the project, but are, in fact, paid for to a large extent by the Government.

As already stated, the Government pays $75 \%$ towards the cost of land consolidation.

The above-mentioned section of the Land Consolidation Act begun to be applied in 1955. Until then land had been purchased but without compensation for loss of profit and obviously there had not been many farmers who were willing to give up farming. The provision included in the new Act is especially important in that it provides for the purchase of land from persons carrying on agriculture as a subsidiary occupation. Actually this category still holds a large percentage of the cultivated land. It is desirable to be able to purchase this land in areas where reform is carried out in conjunction with land consolidation and use it to enlarge undersized farms. 


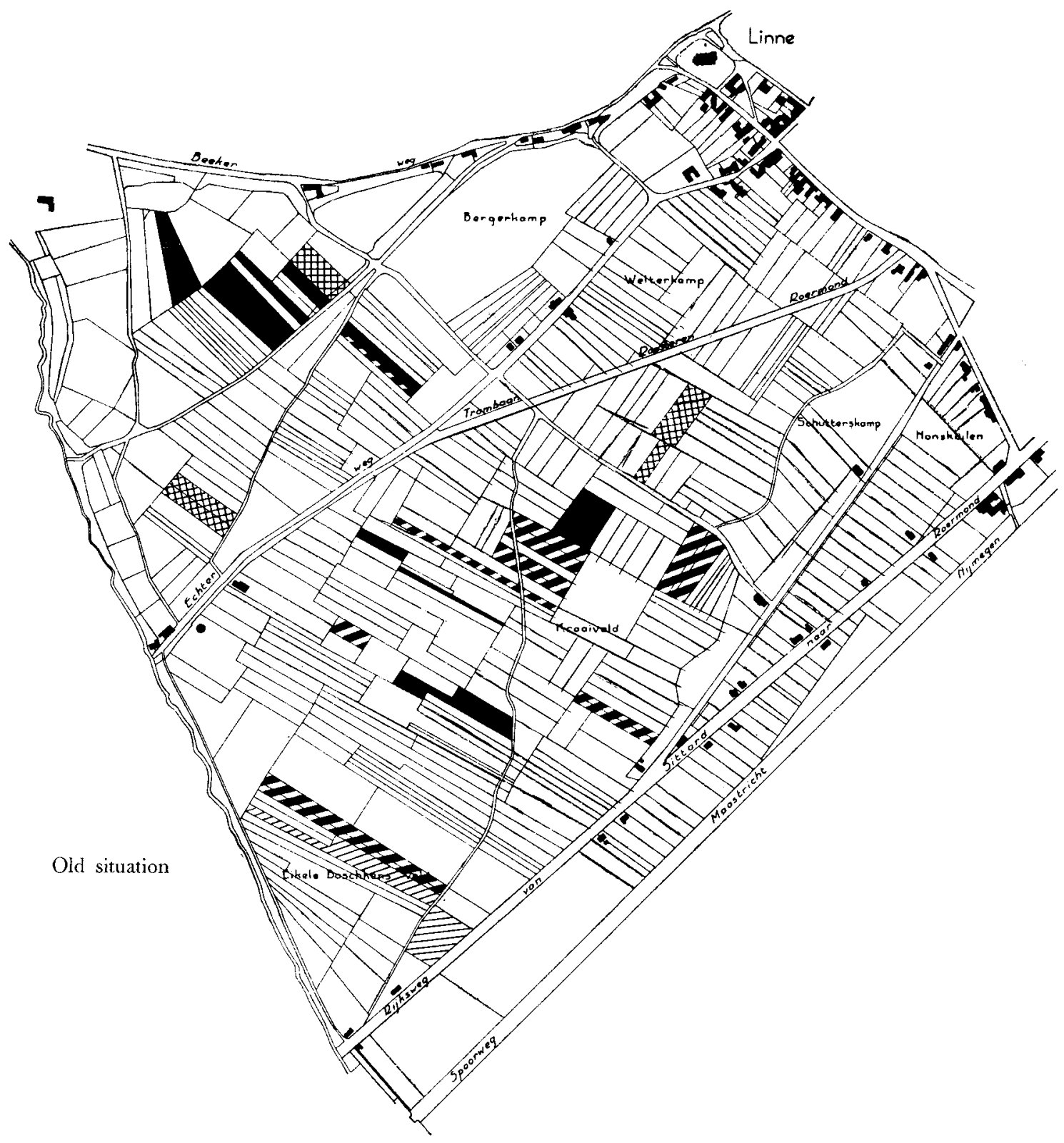

Frg. 8 EXAMPLE OF A LAND-CONSOLIDATION SCHEME. 


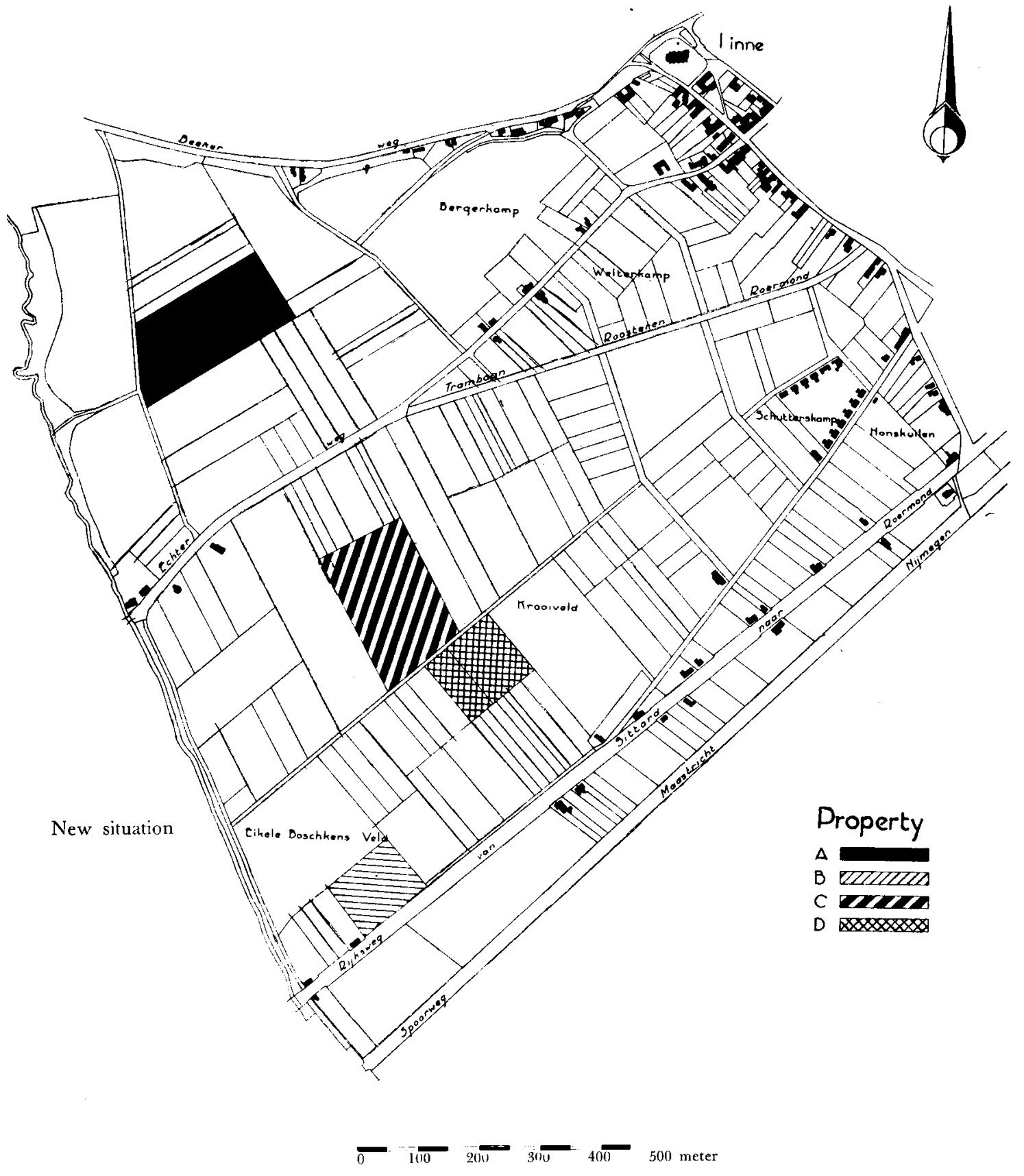




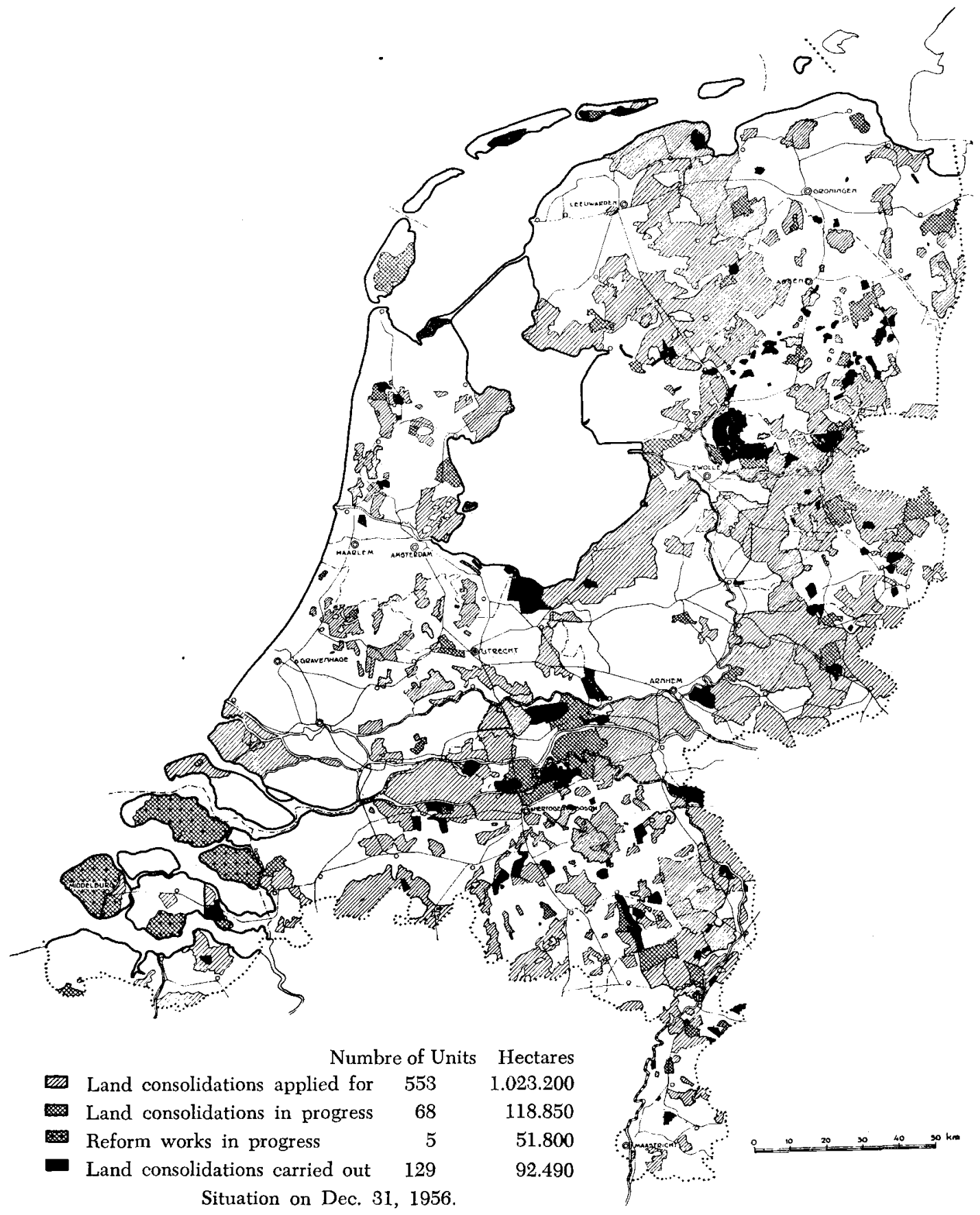

Fig. 9 Land consolidations in the Netherlands. 


\section{Conclusion}

In the Netherlands these land-improvement and farm-economy reforms are considered to be of particular significance for the improvement of the structure of agriculture. The Government is therefore prepared to vote considerable amounts for this purpose. In 1956 an amount of Dfl. $175 \mathrm{mln}$. was spent on land-improvement works. Dfl. $101 \mathrm{mln}$. of this amount went towards the consolidation of fragmented holdings, which therefore constitutes a considerable part of reform. The rest was used to improve the development of areas, with an inadequate road system, and also for the improvement of water control and the construction of farm buildings. A further Dfl. $28 \mathrm{mln}$. has been spent by the Government on bringing the said new Zuiderzee polders into cultivation. It is obviously very important that the reclamation of the Zuiderzee should keep pace with the execution of land improvement works in the old land as this synchronization is the only basis of reform in conjunction with land consolidation.

The Dutch people, and consequently the Government and the States-General as well, are in fact prepared to spend these substantial amounts on structural improvements as they, together with the Minister of Agriculture, Fisheries and Food, are convinced that this is the only method of increasing agricultural productivity so that agricultural products can be produced at sufficiently low cost.

As was already pointed out at the beginning of this article, this is the keynote of continued industrialization and the basis for the maintenance of our export market. It should be remembered that the Netherlands has controlled rents and land prices, with the result that present-day rents have not risen so much as the other cost elements such as wages and other agents of agricultural production which now cost 3 or 4 times as much as in 1940. This means, of course, that from the point of view of private economy investments in land and agricultural buildings are not very profitable because the interest and upkeep can hardly be covered by the rent. This is one of the reasons why the Government is devoting much attention to investments in agriculture. 